\title{
The development of national governance principles in The Netherlands
}

Citation for published version (APA):

van Iterson, A. T. M. (1997). The development of national governance principles in The Netherlands. NIBOR, Netherlands Institute of Business Organization and Strategy Research. NIBOR Research Memorandum No. 08 https://doi.org/10.26481/umanib.1997008

Document status and date:

Published: 01/01/1997

DOI:

10.26481/umanib.1997008

Document Version:

Publisher's PDF, also known as Version of record

\section{Please check the document version of this publication:}

- A submitted manuscript is the version of the article upon submission and before peer-review. There can be important differences between the submitted version and the official published version of record.

People interested in the research are advised to contact the author for the final version of the publication, or visit the DOI to the publisher's website.

- The final author version and the galley proof are versions of the publication after peer review.

- The final published version features the final layout of the paper including the volume, issue and page numbers.

Link to publication

\footnotetext{
General rights rights.

- You may freely distribute the URL identifying the publication in the public portal. please follow below link for the End User Agreement:

www.umlib.nl/taverne-license

Take down policy

If you believe that this document breaches copyright please contact us at:

repository@maastrichtuniversity.nl

providing details and we will investigate your claim.
}

Copyright and moral rights for the publications made accessible in the public portal are retained by the authors and/or other copyright owners and it is a condition of accessing publications that users recognise and abide by the legal requirements associated with these

- Users may download and print one copy of any publication from the public portal for the purpose of private study or research.

- You may not further distribute the material or use it for any profit-making activity or commercial gain

If the publication is distributed under the terms of Article $25 \mathrm{fa}$ of the Dutch Copyright Act, indicated by the "Taverne" license above, 
The Development of National Governance Principles in The Netherlands

A. van Iterson

$\mathrm{NIBOR} / \mathrm{RM} / 97 / 08$

http://www.unimaas.nl/ document/fdewb.htm

J.E.Lit. code: N00

$n i b \circ r$

Netherlands Institute of

Business Organization

and Strategy Research

University of Maastricht

Faculty of Economics and Business Administration

P.O. Box 616

6200 MD Maastricht

The Netherlands

Phone: ++3143 - 3883794 


\section{The Development of National Governance Principles in the}

\section{Netherlands}

Ad van Iterson

NIBOR (Netherlands Institute of Business Organization and Strategy Research)

University of Maastricht

Faculty of Economics and Business Administration

Department of Management Sciences

P.O.Box 616, 6200 MD Maastricht, the Netherlands 


\section{INTRODUCTION}

This paper explores how the connections between governance principles, collective actors and workplace relations have developed in the Dutch business system. In order to identify the governance principles (Kristensen, 1997) which regulate the formation and interaction of social groupings in the Netherlands, attention will first be directed to the geographical and socio-economical characteristics of late-medieval 'Holland' and, next, to the early history of the Republic of the Netherlands (17th century) when the rebellious Dutch provinces gained unity and identity in their combat against the Spanish overlordship and the ubiquitous water, and when merchant elites grasped the opportunities offered by the expanding oversees trade and the favourable location of the maritime part of the Netherlands.

It will be argued that the development of governance principles and the formation of collective economic and institutional actors in the Netherlands, must be understood in terms of: a) the late-medieval and early-modern agrarian and commercial activities (cattle-farming, fishing, and trading), which were not governed by a feudal owner class or centralised kingdom, but supported by municipal bourgeois ('burghers'), b) the winning of land from the sea and securing it through dikes and dams, which has seen the rise of partly voluntary associations, founded on the cooperative principles of quasi-government through peer control, and, c) the emergence of large trade companies, 'proto-MNCs', which were coordinated by a group of 'Heeren' ('Gentlemen'): rather collegiate 'management teams' representing the interests of local and regional governments. These phenomena and processes have generated a distinctively Dutch pattern of constituting and regulating social groups which continues to dominate work organisation and workplace relations in the Netherlands. The central regulatory or governance principle that has become established can be summarised as the strong preference for compromise and consensus among peers, and I shall conclude the paper by a brief disciussion of how this has continued to influence the functioning of large complex organisations that developed in the 20th century. 


\section{LATE-MEDIEVAL AND EARLY-MODERN DUTCH SOCIAL AND ECONOMIC DEVELOP- MENT}

The development of organized economic activities in the Netherlands can roughly be divided into three phases:

Phase 1: from the Middle Ages to the end of the 16th century. This is the period of the formation of larger and larger territorial unities, which eventually were united in the Habsburgian empire of Charles V and Philips II. This period ended with the revolt against the latter and the establishment of the Republic of the United Provinces.

Phase 2: from the end of the 16th to the end of the 19th century. This is the period of i) the Republic of the United Provinces, which ended in 1795, when the Republican regime was overthrown by the revolutionaries ('Patriotten'), backed by the French military force, ii) the Batavian Republic (1795-1806), a vassal state of the French Empire, and iii) the early decades of the kingdom of the Netherlands which was established after Napoleon's defeat in 1813.

Phase 3: from the beginning of the 'second industrial revolution' (the introduction of electrical and chemical industries in Western countries), which commenced about 1880, up to the present. $^{1}$

In the first phase, which ended with the 1572 Revolt or the 1579 establishment of the Republic, there was no Dutch state, society or identity. But, as in other parts of Western Europe, one witnessed in the Rhine and Maas delta, too, a process of i) feudalisation, ii) state formation, and iii) emergence of an absolutist monarchy. However, and this is crucial for our understanding of Dutch first-order governance, this process took a specific course, here. Especially in the maritime provinces of Holland and Zeeland, feudalisation was much more limited in impact than in the eastern and southern provinces, let alone the further hinterland. This is not surprising given the fact that these low-lying zones, surrounded by water and moors and a frequent prey to tidal waves and river floods, were a territory difficult to get at. Therefore, this outpost of the (weakening) German Empire was quite insuitable for the formation of a military- 
agrarian society, in which semi-autarkic farmers lived in dependence of a warrior class. Peasant farmers were free from feudal ties and obligations already from the 12th century onwards. Land reclamation and colonization of new territories urged the nobility and the church to offer attractive terms and free status, in order to entice peasant farmers to work these newly cultivated areas as well as counter the attraction of migration to the same type of land in Germany (e.g. van Houtte, 1964: 48-52). Faster than in England or France, then, land were leased out to peasant farmers, free from seigneurial control, for short-term money rents. By 1500 , the larger part of the Low Countries was in held in fee simple. ' $[\ldots]$ the tendency was to parcellize the land into small spots, whether it belonged to nobles, the Church, towndwellers, or to small farmers themselves. In the newly colonized areas of the polders, the countryside became covered with large numers of medium-sized farmhouses, [..] on small parcels of land, of standard size, deemed sufficient to support individual families. It was a trend which minimized both seigneurial influence and the pull of village institutions' (Israel, 1995: 106). Even ancient common fields were parcelled out to small farmers. Increasing specialisation and intensification, then, rendered Dutch agriculture an extremely high productivity - in fact, the highest in the world.

Instead of the development of an agrarian-feudal society, one witnessed already in the 13th and 14 th century a remarkable rise of the cities. The absence of a warrior nobility striving for extensive ruler rights offered the town-dwellers the opportunity to specialise in commercial activities. Now, the same omnipresence of water (sea and rivers) explains why economic expansion was found in fishing, carrying and transshipment. Already in the first half of the 15th century, the Hollanders and the Zeelanders developed the full-rigged herring buss, which endured their dominance over the North Sea herring grounds for three centuries, and the seagoing ships which formed the basis of the rapidly increasing bulk-carrying traffic between the Baltic (grain and timber) and western France and Portugal (salt). Herring fishery, bulk freightage, and also the extensive river traffic stimulated an array of supportive activities: shipbuilding, the production of ropes, sails, barrels, casks, sacks, as well as equipping and 
manning.

As the peasant farmers were included in nascent urban trading networks, chances did increase for both groups: cattle-farmers and fishermen as well as craftsmen and merchants. Also profiting were the related small-scale manufacturing industries in the cities, notably in 'inland towns' such as Leiden, Haarlem, Delft and Gouda. In these shipyards, ropewalks, breweries and other 'manufacturen', and in sugar refineries, soap works, tobacco processors and other 'trafieken', expert knowledge of commodities and craft production were crucial.

The productive co-operation between peasantry, commerce and industry brought about a strong population growth which again contributed to the on-going process of urbanisation. At the beginning of the 16th century, nearly half of the population of Holland lived in cities - a situation only paralleled by Flanders and the Venice region (de Vries and van der Woude, 1995: 86) - and these cities were usually not governed by the nobility.

The relatively weak position of feudal lords in the Dutch maritime zone contributes to the explanation why the Netherlands did not develop into an absolutist monarchy in the following centuries. The attempts of the Burgundian dukes (particularly Charles the Bold) and, later, of the Spanish Habsburg kings Charles V and Philip II, both centred in Brussels, to bring the 'Dutch' provinces under strong imperial rule, which finally seemed to succeed in 1543 , met strong resistance, however, and failed in the end: the Dutch Revolt resulting in the Eighty Years' War. The result of this revolt and war was the establishment, in 1648, of a sovereign republic of seven sovereign provinces (Holland, Zeeland, Utrecht, Friesland, Groningen, Overijssel and Gelderland). Only after that event, national institutions were developed, and, among the elites, a national identity awoke (Goudsblom, 1988: 36).

This is not to say that the Netherlands evolved into a strongly centralised nation itself. On the 
contrary. It has often been remarked that the political structure of the young republic was an 'anachronism': it still preserved local and provincial autonomy and privileges, whereas the emerging absolutist states had abolished these practices. Yet, at the same time the Dutch republic is as often labelled as strikingly 'modern' (e.g. de Vries, 1973), since the state, the provinces and the cities were governed by urban elites where the nobility was outnumbered by the burghers. The 'States General' (the Dutch legislative body) was dominated by the nonaristocratic patricians from the cities, of which there was not one enjoying absolute power, despite Amsterdam's leading position. An important feature of these States General was its decision-making: the most important issues required unanimity of the voting provinces. This, again, demanded time-consuming persuasion and mutual adjustment. The same applied for the provincial legislative bodies: the seven Provincial States. As to the executive, the 'Stadtholder' (a position held by the successive princes of Orange) had to share considerable power with the Grand Pensionary, Holland's highest civil servant. The very position of the stadtholder, officially the 'servant of the States General', was questioned by the municipal elites, above all Amsterdam, leading to a - albeit short-lived - 'eternal edict' (1667) by which the stadtholdership was abolished.

Compared with the model example of state formation - feudal France into absolutist France (see: Elias, 1969) - the Netherlands, too, had its Sondergang and an early one to boot: nonfeudal 'Holland' into non-absolutist Republic. The seemingly paradox between the anachronistic and modern political system accounts to some extent for the simultaneous existence of traditional forms of small-scale co-operation on the basis of peer control ànd large-scale trade organisations such as those active in the Baltic grain and wood trade as well as the Verenigde Oostindische Compagnie (the Dutch East India Company; 1602-1798) and the Verenigde Westindische Compagnie (the Dutch West India Company; 1621-1648), the first one being the world's first limited liability company and the largest multinational trading firm in the 17th and 18th century (Gaastra, 1989, 1991). Also profiting from the open spirit of bourgeois enterprise 
were the (mainly Amsterdam) merchant-banking houses, which operated largely on the international market as well.

\section{THE COLLECTIVE EFFORT OF DRAINAGE AND LAND RECLAMATION}

The 13th century 'not only witnessed the start of this vast drama [of drainage and land reclamation, avi], one of the most impressive of all examples of man's cumulative impact on his physical environment ${ }^{2}$, but was the period in which evolved the institutional and juridical apparatus needed to sustain it.' (Israel, 1995: 10). To fund, build and maintain dikes, dams and drainage channels, local drainage and polder boards developed. These heemraadschappen were committees on which villages, towns and local nobles had their representatives, providing a mechanism for cooperation between them. As stated in the introduction, these heemraadschappen were not family- nor state-initiated, but 'local and spontaneous in origin' (Ibid.): partly self-organized groups of experienced water tamers, so to say, and therefore often labelled as 'original democracies'. Already by the early thirteenth century, however, the count of Holland, and neighbouring princes, exerted a growing influence on this already vital framework of dike, drainage, and waterway control, especially by setting up regional jurisdictions to oversee the work of the drainage and polder boards: the hoogheemraadschappen (hoog - high). These were also committees of representatives of towns, rural localities, and the nobility. But their procedures were fixed by the count and presided over by a dijkgraaf, a 'dike count', which, in Zeeland and Holland, was often one of the count's district officials, who combined his role in flood control and dike maintenance with policing, fiscal and judicial responsibilities. Nonetheless were these regional boards limited in reach, and, because of their character of proportionality, not contradictory to the associations on which they were superimposed.

In the 17th century, the States General took over the supervising of the water defenses, the drainage boards, and land reclamation projects. The sea dikes, river embankments and 
'polders' continued to be maintained mainly by the regional boards, but in the case of new drainage projects, where there were often rival interests, the role of the States was fundamental. In the draining of the Schermer lake, near the city of Alkmaar, in 1631, 'prolonged negotiations took place with the States mediating between Alkmaar, a group of investors in Amsterdam, and the local drainage boards' (Israel, 1995: 284). This example already indicates that supervising in the Netherlands often takes the shape of mediating.

Plessner (1974) has argued that the Dutch, in the winning of peat bogs, in the putting up of dams and dikes and in the regulation of water via drainage channels, learned to do teamwork in a rational way. We have seen that these teamwork activities, unlike later efforts in other estuary areas (e.g. the Ganges delta), were not initiated nor coordinated by any central government. Instead, the making of the Dutch landscape (see: Lambert, 1985) was mobilised by volunteering farmers and citizens, with some aid of the local government. Upon these initiatives, governed through peer control, one has seen the rise of the above-sketched regional organisations. These formal agencies, too, were 'founded on the traditional Germanic cooperative principles of quasi-government through peer control' (Sorge and van Iterson, 1995: 191). Therefore, both these local and regional water district boards are regarded here as one of the craddles of the (maritime) Dutch governance principle of consensus building via peer control of representatives of local interests. Another craddle of natural governance in the maritime provinces can be found in the large-scale trade companies which were active in the Far (South) East, in South- and West-Africa, in Brazil and in the Carribean.

\section{LARGE-SCALE TRADE AND COLONIAL ENTERPRISES: THE PROTO-MULTINATIO-}

\section{NALS}

The East and West India Companies might very well have served as a blue print for the Dutch MNCs of late eras. It is, for instance, suggested that the East India Company (the 'VOC') 
offered a bureaucratic model for integrating commercial and colonial interests, which was adopted by 19th century trade organisations such as the Nederlandsche Handelsmaatschappij. One could argue that the VOC also offered a paragon for integrating the need for adhering to the consensus and coalition model of the 'home country' (Holland) and the opportunity to utilise the natural and human resources of the `host country' (particularly Indonesia).

The highest managerial functions of the VOC were in the hands of the Heeren XVII ('Gentlemen XVII'), who were assisted by advisory committees on issues such as accounting and auctions. These seventeen functionaries represented local boards of directors: the six kamers ('chambers'). The kamer Amsterdam supplied eight representatives; kamer Zeeland four; and Delft, Rotterdam, Hoorn and Enkhuizen each one. The seventeenth Heer was alternating a representative of one of the five smaller chambers, so that Amsterdam could never overrule the others (Gaastra, 1989).

The kamers set the agenda of the Heeren XVII: the representatives were given order to bring certain topics forward for discussion and decision and how to vote. Especially the Amsterdam and Zeeland chambers, with 12 or 13 of the 17 votes at highest level, were quite powerful. In return, these two chambers were commissioned by the Heeren XVII with three-quarters of the controlling tasks (Amsterdam 1/2; Zeeland 1/4), such as bookkeeping and supervision of storage and shipbuilding, and of the operational tasks. Despite the dominant position of particularly Amsterdam, the VOC's higher managerial levels were strikingly horizontally decentralised, parallel to the social and political structure of the Republic. Another strikingly 'modern' feature is that managerial discretion from owners was high. Shares were remarkably widely dispersed (Van Dillen, 1958). And although these shareholders were represented by nine 'participants' to the meetings of the Heeren XVII, they had only an advisory role. Their complaints about the entanglement of commercial and political interests were not taken to heart. 
This undoubtedly influental example learns that early-modern Dutch 'top management' operated as teams of equals, promoting the interests of stakeholding local parties rather than exclusively those of owners. For sure, this idiosyncratic pattern fits well with the contemporary situation in Dutch business, where both the executive and the supervisory board ${ }^{3}$ are supposed to consider the interests of all stakeholders - suppliers of capital, management, workforce and the general public alike (Schreuder, 1981). Therefore, the Dutch firm could be labelled as a 'nexus of stakeholders' (van Iterson and Olie, 1992) where none of the collective actors involved dominates.

\section{INDUSTRIALISATION AND THE FORMATION OF COLLECTIVE ACTORS}

The rise of the Republic of the United Provinces to world leadership in oversees trade and in agricultural productivity was nothing less than a divergent path to industrialisation. Dutch industrialisation can only be qualified as 'retarded' if one compares it with the English 'Industrialisation Revolution' (de Vries and van der Woude, 1995), which comprised large-scale application of steam-driven technology in the so-called factory system (e.g. Landes, 1969; see also Kristensen, 1997). What contributed to the Republic's early prosperity, were technological innovations of a different nature to the flying shuttle, the blast-furnace and the steam engine. These innovations are to be found in precisely the sectors discussed above. Drainage, farming and manufacturing profited greatly from the advanced windmill technology; fishing and bulk freightage from the indroduction of the fast 'fluit' ship, which enabled the Dutch to sail to the Baltic twice a year in stead of once. In addition, one can refer to fodder crops, methods of soil replenisment, improved sluices, harbour cranes, timber-saws, and textile looms (e.g. Davids, 1993). These examples already indicate that these innovations were above all improvements of traditional devices. ${ }^{4}$

An essential element if the trade-oriented 'industrialisation' was the unparallelled knowledge of commodities of the Dutch (Wennekes, 1996), but also knowledge of classifying, testing, 
storing, transporting, processing and market these commodities. These skills have become an enduring strength of a large number of Dutch firms in the industrial processing of drinks and foodstuffs (e.g. Unilever) and in the field of transport by road (e.g. Frans Maas) and air (e.g. KLM). The continuity between the early-modern and the present era accounts for the seemingly paradox that the Dutch economy has 'come to be focused on activities which are elementary and yet highly modernised and capital intensive, simultaneously pre- and postindustrial due to a high service sector share in total employment: about 72 per cent at present (including government)' (Sorge and van Iterson, 1995: 191) and to 'the prevalence of very productive large enterprises in process industries' (Ibid., p. 192). Now, because of this very continuity between the pre- and postindustrial Dutch business system, it can be expected that the natural governance, which has developed in the 13th to 17th century, is still viable in the work systems of present enterprises, both small- and large-scale. Before that, however, the formation of collective actors, competing over social and economic space in modern Dutch organizations, has to be discussed. The resulting constitution of an industrial order in the Netherlands was largely determined by the strong vertical ideological segmentation between these collective actors, known as the 'pillarisation' or Verzuiling (Lijphart, 1968), a nationally distinct socio-institutional phenomenon which has lost much of its central role in Dutch society only in recent decades.

Soon after its establishment as the state religion of the young Republic, Dutch protestantism proliferated in a plethora of doctrines, denominations and sects, which fragmented loyalties dramatically. Being a small, vulnerable nation, caught in an enduring fight with England, which lead to four seawars, this fragmentation, however, needed to be overcome, at least among the elites involved, through coalitions. This led to a pattern of 'segregation at the bottom, coalitions at the top'. In the 19th century, when the (for centuries second-rate citizens) Roman-Catholics, as well as the non-confessional newcomers (radical and revisionist socialists) 'emancipated' and joined the public arena, this pattern found strong enforcement through institutionalisation. Political parties, schools, mutual health and social insurance, trade 
unions, professional organizations and other secondary associations, were established along these confessional and political lines. This resulted in a strongly corporatist system, which one probably would not expect in such an 'open', trade-oriented nation as the Netherlands.

The pillarisation has reinforced the Dutch natural governance of compromise and consensus. Since neither of these different religious and ideological groups has gained absolute power in any domain, coalition building involving compromise seeking was the only way to come to decisions and to find steady governance. On first thoughts pillarisation seems to contradict consensus and compromise. But, as already indicated, pillarisation did not occur along class divisions, but ran counter to these, so that owners, managers and workers could 'find each other' in the intitutionalised defense of, for example, Roman Catholic interests. In other words, pillarisation has reinforced the consensual spirit within the pillars.

These pillars, standing firmly seperated from each other, carried the same roof: 'The Netherlands Ltd.', as Dutch society is often ironically called. Pillarisation, in the words of Van Dijk and Punch, is `a structure of vertical divisions [..] which parcelled out institutions along religious/ideological lines in a way which minimized conflicts between the "pillars". At the top, a relatively small elite bargained for the division of the spoils among the contending pillars and developed a model based on consensus, negotiation, paternalism from the top, and of "nonaggression treaties" to avoid disruptive conflict among, and open embarrasment of, elite members' (van Dijk and Punch, 1993: 172).

This corporatist framework, with the accepted role of 'pillarised' associations at 'mid-field' level, and the power balance between them, has also strongly affected the governance of work sytems in firms, particularly in joint-stock companies. Both in the operative codetermination system, with the accepted role of the trade unions and the works councils ${ }^{5}$, and in the predominating concept of the firm as a nexus of stakeholders where neither of the parties dominates, coalition building and consensus seeking are mandatory to achieve 
business goals. Despite their large managerial discretion, as a result of dispersed share ownership ${ }^{6}$, but also of a failing market for corporate control and arm's length relations with governmental and financial institutions ${ }^{7}$, executive boards in the concentrated sectors and industries pursue the public interest of the company and not the partial interests of owners, management itself, workers or any other collective actors. This commitment to the firm's interest as a whole is even expected from the works council, which is, of course, officially the representative body of the work force.

\section{NATURAL GOVERNMENT IN MODERN LARGE-SCALE BUSINESS UNITS}

The Dutch pattern of corporatist industrial organisation largely gave way to a more 'liberal' order in the 1970s and early 1980s. This must be understood in relation to the fact that the contemporary Dutch business is marked by an 'hour-glass' structure: a huge number of small firms (about half a million registered companies have less than 10 employees), one the one hand, and some 20 very big multinationals with world-wide operations, on the other hand, and with only precious little in between (van Iterson and Olie, 1992: 98). In a number of industries, the concentration degree is indeed remarkably high. First of all, there is a highly concentrated sector of large enterprises which further process natural inputs, largely in the food and drinks industry (e.g. Unilever). In addition, there is a large, concentrated chemical industry, which is similar to the previous industry in production process type (e.g. Shell, DSM and AKZO). Finally, one also has to count the Dutch electronics and electrical engineering among the concentrated multinational industries (Philips). Now, these capital intensive multinationals prefer to operate as independent as possible, or have only loose sub-contracting relations with firms 'below the waist', which are both quite different from the cooperative and corporatist principle. ${ }^{8}$ These preferences of powerful economic actors, in combination with the secularisation process of 'de-pillarisation' in the wider society, finally finished corporatism off. 
This is not to say, of course, that the same lot fell to the Dutch regulatory principles of compromise and consensus between peers.

The very size of operations of these large enterprises and the technical system used - mass and process production - point clearly in the direction of Taylorist work systems. No doubt, job fragmentation and managerial coordination of complementary porcesses (see Whitley, 1997) are reasonably high in the largest MNC's production units. But the separation of managers from workers, however, is much lower than in comparable units in the Anglo-Saxon world or in France and Belgium. There are numerous accounts of the low power distance between managers and workers in Dutch enterprises. The management ethos is one of aversion against overt display of power or hierarchical differences (Lawrence 1991: 128-135). According to Van Dijk and Punch, '[t]he Dutch context [..] is more conducive to styles that allow for participation than to more authoritarian styles' (1993: 182). And many Dutch managers 'continually anticipate the expected acceptability of their proposals by subordinates' (Ibid., p. 183). Neither is formal, task-oriented leadership, as one encounters in Germany, the main basis for authority in the Netherlands. Persuasion power is most important, followed closely by expertise. The Dutch manager has to be a problem solver, but not without consulting peers and lower hierarchical levels. Above all, he/she is expected to nurture group relations (Lawrence, 1991). Consequently, one is inclined to argue, worker discretion must be higher than one would expect in large, mass- or process production units, also because of the accepted role and prominent role of the unions and the works council. Dutch work sysrtems are more similar to 'negotiated' than Taylorist ones in Whitley's terminology then, although d'Iribarne, (1989) has suggested that such negotiations may be more ceremonial than real.

He argues that while the spirit of compromise ('l'esprit de compromis') and the quest for consensus ('la recherche de consensus') still regulate modern work organisations, 'real' peer control in (semi-)autonomous work teams is exceptional. For sure, Dutch managers, be it in 
small-sized firms or in the large multinationals, show `a willingness to listen, to talk, to consult, to explain, to restrain from verbal violence and directives on authority' (Ibid., p. 243). Furthermore, they 'evade to impose a measure without allowing the people concerned the time to understand and accept it' (Ibid.). But it is exactly here that for d'Iribarne the other side of the coin becomes visible. Dutch consensus modern style means that management duly informs, consults and, if necessary, soothes the employees before decisions are taken. But the final decisions are taken in the board rooms rather than on the work floor. 'Le consensus néerlandais', then, is a means to manage tensions in work systems.

Overall, then, there remains the question of the extent to which large Dutch enterprises succeeded in reconciling the prevailing governance principles outlined above with the demands of coordinating bureaucratic units producing for the world market? Maybe there is little to reconcile. Maybe the Dutch have learned to live with yet another paradox or seemingly conflicting demands. Maybe the Dutch can cope well - or at least reasonably well - with the problem of adversial regulatory principles: natural versus superimposed governance. It would not be the first time that their ability to capitalise on ambivalence is tested and proven. These intriguing questions need to be explored further.

\section{List of References}

Brunstein, I. (1995) (ed.), Human Resource Management in Western Europe (Berlin: De Gruyter.

Davids, C.A. (1993), 'Technological Change and the Economic Expansion of the Dutch Republic, 1580-1680', in Davids and Noordegraaf 1993: 79-104.

Davids, K., and Noordegraaf, L. (1993) (eds.), The Dutch Economy in the Golden Age: Nine Studies, (Amsterdam).

Dijk, N. van, and Punch, M., (1993), 'Open Borders, Closed Circles: Management and Organization in the Netherlands', in Hickson (1993), 167-90.

Dillen, J.G. van (1958), Het oudste aandeelhoudersregister van de Kamer Amsterdam der 
Oost-Indische Compagnie, (The Hague).

Elias, N. (1969; 1939), Über den Prozess der Zivilisation, (Frankfurt am Main).

Ferner, A., and Hyman, R. (1992) (eds.), Industrial Relations in the New Europe, (Oxford).

Gaastra, F.S. (1989), Bewind en beleid bij de V.O.C. 1672-1702, (Zutphen).

- (1991), De geschiedenis van de V.O.C, (Zutphen).

Goudsblom, J. (1988a), 'De Nederlandse samenleving in ontwikkelingsperspectief', in Goudsblom (1988b), 30-68.

— (1988b), Taal en sociale werkelijkheid. Sociologische stukken, (Amsterdam).

Harzing, A.-W., and Ruysseveldt, J. van (1995) (eds.) International Human Resource Management, (London).

Hickson, D. J., (1993) (ed.), Management in Western Europe. Society, Culture and Organization in Twelve Organizations, (Berlin/New York).

Houtte, J.A. van, (1964), Economische en sociale geschiedenis van de Lage Landen, (Zeist). d'Iribarne, Ph. (1989), La logique de l'honneur: Gestion des entreprises et traditions nationales, (Paris).

Israel, J. (1995), The Dutch Republic. Its Rise, Greatness, and Fall 1477-1806, (Oxford). Iterson, A. van, and Olie, R. (1992), `European Business Systems: the Dutch Case', in Whitley (1992), 98-116.

Koene, A.M., and Slomp, H. (1991), Medezeggenschap van werknemers op ondernemingsniveau: een onderzoek naar de regels en hun toepassing in zes Europese landen, (The Hague).

Lambert, A. (1985), The Making of the Dutch Landscape, (London).

Landes, D. S. (1969), The Unbound Prometheus, (Cambridge).

Lawrence, P. (1991), Management in the Netherlands, (Oxford).

Lijphart, A. (1968), The Politics of Accommodation: Pluralism and Democracy in the Netherlands, (Berkeley, LA).

Plessner, H. (1974), Diesseits der Utopie, (Frankfurt am Main).

Schreuder, H. (1981), Maatschappelijke verantwoordelijkheid en maatschappelijke 
berichtgeving van ondernemingen, (Leiden).

Slomp, H. (1995), 'National Variations in Worker Participation', in Harzing and van Ruysseveldt (1995), 291-317.

Sorge, A., and Iterson, A. van (1995), 'Human Resource Management in the Netherlands', in Brunstein (1995), 191-209.

Visser, J. (1992), 'The Netherlands: the End of an Era and the End of a System', in Ferner and Hyman (1992), 323-356.

Vries, J. de (1973), 'On the Modernity of the Dutch Republic', Journal of Economic History, 23, 191-202.

- and Woude, A. van der (1995), Nederland 1500-1815. De eerste ronde van moderne economische groei, (Amsterdam).

Wennekes, W. (1996), Gouden handel. De eerste Nederlanders overzee, en wat zij daar haalden, (Amsterdam).

Whitley, R. (1992) (ed.), European Business Systems. Firms and Markets in their National Contexts, (London). 
1. This classification does not corresponded with the generally accepted three-phases distinction in Dutch history (e.g. Goudsblom, 1988), in which the third phase already starts with the Treaty of Vienna in 1815, when the present Kingdom of the Netherlands was established. Although this classification is largely political, it is claimed to correspond with `more general phases in the social development, which, next to the Netherlands, apply also for others parts of Western Europe' (Ibid., p. 32). For my purpose, however, this distinction is not appropriate since it neglets the so-called 'industrial retardation' of the Netherlands: large-scale application of steam technology in the factory system did not coincide with the formation of the modern state, as it did in the neighbouring countries Belgium and Germany. For this reason it makes much more sense to let the third phase of Dutch economic development commence in 1880 , when this type of industrialisation finally 'took off'. The period between 1813 and 1880, then, must largely be seen as a prolongation of the trade, transport and banking era which started about 1600 . It will be suggested in this contribution that this era of 'trade capitalism' or 'entrepot economy' was characterised by its own variant of 'industrialisation': evidently not through the introduction of steam technology, but via other forms of mechanisation and rationalisation.

2. Note that between the 13th and 15th century more land was reclaimed from the sea, river estuaries and lakes than in the early modern times.

3. As in Germany, Dutch public companies have a two-tier board system. Dutch supervisories. however, are not appointed by the shaeholders or by the workforce, as in Germany, but by cooption.

4. Sophistication was also achieved in finance and accounting as well as warfare and punishment, but also in these fields one noticed rationalisation of existing techniques rather than revolutionary breakthroughs.

5. Trade unions exert influence mainly at national and industry level, although company collective agreements are becoming more and more important in the Netherlands (e.g. Visser, 1992). The unions are also active at firm level, mainly via the works councils, where union membership ratios are high: about 75 per cent. Dutch works councils are not constituted to have a top management member or to be a pure consultation and information committee, as in France and Belgium (Koene and Slomp, 1991; summarized in English in: Slomp, 1995). Dutch works councils are independent consultation and bargaining agents, elected by the entire work force. They enjoy co-determination rights roughly similar to those in Germany. Furthermore, they also have the right to object to a new supervisory board member. 'All 
considered, they have a comparatively strong position in the manufacturing of consensus in the enterprise, Dutch style' (Sorge and van Iterson: 1995: 206).

6. Except for a small number of family-owned firms, such as Heineken, Vendex International and SHV Holdings), all modern Dutch multinationals are public limited liability companies, quoted on the Amsterdam Stock Exchange, where shares are usually widely dispersed.

7. Unlike in France, for example, the Dutch state has never really acted as a strong coordinator of economic activities, both with respect to trade and industry. This is not surprising given the long trading tradition, the large export sector and the dominant role of large multinationals with major operations abroad. As to financial institutions, the Dutch banks never engaged in large-scale participation in national industry. Being much more commercial than investment banks, they specialised in short-term credit provisions and trade finance.

8. Only in the agro-related sector (dairies, marketing of food), the cooperative and corporatist principle is still strong. 